The different feeding treatments, which affected the fatty acids profile, did not affect the sensory quality of the meat as found by tasting panels. The tasting panels rated samples of meat from 1-7 for aroma, flavor, hardness and juiciness. There were no statistically significant differences between the groups in neither of the above parameters.

It may be concluded that in the present study changes obtained in the fatty acid profile of adipose tissues and leg muscle fat, due to variation in food composition, were not reflected in the sensory quality of the meat.

Key words : Kid, adipose tissue, muscle fat, fatty acids, diet.

\title{
Growth, efficiency of conversion and carcass composition of castrate male Saanen and Saanen $\times$ Angora kids on a concentrate diet
}

\author{
T.T. TREACHER (1), A. MOWLEM ${ }^{(1)}$, R.M. WILDE ${ }^{(1)}$, B. BUTLER-HOGG ${ }^{(2)}$ \\ (1) The Animal and Grassland Research Institute, Hurley, Maidenhead, \\ Berkshire, SL6 5LR (United Kingdom). \\ (2) Food Research Institute, Langford, Bristol BS18 $7 D Y$ (United Kingdom).
}

The British Saanen (S) is the dominant breed in the small milk goat industry in the U.K. At present few male kids are reared commercially. It has been suggested that Angora (A) goats, which were introduced for fibre production, have better growth and carcass characteristics than pure Saanen. An experiment was designed to assess the potential growth rate and conversion efficiency of these kids and define suitable slaughter weights.

Castrate male kids (34 S and $12 \mathrm{~A} \times \mathrm{S}$ ), that had been reared on a milk replacer to 8 weeks of age, were placed in individual pens and fed a concentrate diet ad libitum together with $150 \mathrm{~g} /$ week of hay. At 10 weeks of age eight $S$ kids were slaughtered at mean live weight of $21 \mathrm{~kg}$ (range $16-26 \mathrm{~kg}$ ). The remaining $S$ kids were allocated to treatments and slaughtered as each individual reached 29,37 or $45 \mathrm{~kg}$ liveweight. Six A $\times \mathrm{S}$ kids were slaughtered at 29 and at $37 \mathrm{~kg}$.

\begin{tabular}{|c|c|c|c|c|c|}
\hline Liveweight interval $(\mathrm{kg}) \ldots \ldots \ldots$ & \multicolumn{2}{|c|}{$21-29$} & \multicolumn{2}{|c|}{$29-37$} & $37-45$ \\
\hline Breed & $S$ & $A \times S$ & $S$ & $A \times S$ & $\mathrm{~S}$ \\
\hline Concentrate DM intake $(\mathrm{g} / \mathrm{kg} /$ day $)$ & 34.0 & 28.4 & 32.0 & 25.6 & 27.6 \\
\hline Growth rate $(g /$ day $) \ldots \ldots \ldots \ldots$ & 209 & 128 & 204 & 127 & 201 \\
\hline Conversion (g lwt gain $/ \mathrm{kg}$ conc) & 251 & 181 & 197 & 154 & 181 \\
\hline
\end{tabular}

Intake of concentrates by $\mathrm{S}$ kids increased from a mean $850 \mathrm{~g} /$ day during gain from $21-29 \mathrm{~kg}$ to $1130 \mathrm{~g} /$ day in the interval from $37-45 \mathrm{~kg}$ but intake relative to liveweight decreased from 35 to $28 \mathrm{~g} / \mathrm{kg}$, a little lower than those of lambs on a similar diet. The growth rate only declined very slightly over the three growth intervals but conversion efficiency decreased by $28 \%$. The A $\times \mathrm{S}$ kids had lower intakes, growth rates and efficiencies of conversion than $\mathbf{S}$ kids.

\begin{tabular}{|c|c|c|c|c|c|c|}
\hline Breed & S & $\mathrm{S}$ & $A \times S$ & S & $A \times S$ & $S$ \\
\hline Liveweight at slaughter $(\mathrm{kg})$ & 21.0 & 29.9 & 29.5 & 37.6 & 37.0 & 45.5 \\
\hline Carcass weight & 9.1 & 14.3 & 14.9 & 18.8 & 20.5 & 24.0 \\
\hline \multicolumn{7}{|l|}{ Percentage in carcass of: } \\
\hline$\ldots \ldots \ldots \ldots$ & 24.1 & 19.1 & 16.4 & 18.6 & 14.6 & 15.5 \\
\hline Muscle & 63.0 & 61.6 & 59.1 & 59.8 & 56.0 & 59.8 \\
\hline Subcutaneous fat & 4.0 & 6.1 & 9.5 & 6.8 & 12.5 & 8.6 \\
\hline Intermuscular fat & 8.9 & 13.2 & 15.0 & 14.7 & 17.0 & 16.0 \\
\hline
\end{tabular}


Total fat as a percentage of the S carcasses increased from $13 \%$ at $9 \mathrm{~kg}$ to $25 \%$ at $24 \mathrm{~kg}$. Subcutaneous fat as a percentage of total fat was low and increased only very slightly from 31 to $35 \%$ with increasing carcass weight. A $\times \mathrm{S}$ carcasses were fatter and had a greater proportion of subcutancous fat than the $\mathrm{S}$ carcasses.

Key words : Kid, Angora, Saanen, growth, feeding, carcass.

\title{
Ralgro implants as a growth-promoter for Saanen male kids
}

\author{
S. LANDAU \\ Extension Service, Ministry of Agriculture, Yaakov, 3, 76262, Rehovot (Israël)
}

The effect of Ralgro implants ( $12 \mathrm{mg}$ Zeranol) to intact weaned male kids on growth and behaviour was investigated in two feeding experiments : in both experiments, the kids were fed a concentrate Ad libitum $(2.6 \mathrm{Mcal}$ of Metabolizable Energy, $16 \%$ Crude Protein, $1 \% \mathrm{Ca}, .45 \%$ $\mathrm{P}$, and $22 \mathrm{ppm}$ monensin-sodium, on an as-fed basis), and a daily allowance of 100 grams wheat straw. In experiment 1 , five kids were first implanted at the age of 75 days and reimplanted 42 days thereafter ; five unimplanted contemporary kids were used as control. The initial body-weight $(\mathrm{kg})$, average daily gain $(\mathrm{g} / \mathrm{d})$ on days $1-42$ and $1-70$, and feed efficiency ( $\mathrm{kg}$ concentrate $/ \mathrm{kg}$ gain) of the treatment and control groups were $12.6,252,250,3.5$ and $12.7,219,212,4.0$, respectively.

In experiment 2, 6 kids were implanted at the age of 86 days, and 6 kids served as control. All the kids were kept 30 days on experiment. The initial body-weight $(\mathrm{kg})$, average daily gain $(\mathrm{g} /$ d) and feed efficiency of the treatment and control groups were 15.7, 250, 2.9 and 14.7, 228, 3.4, respectively.

The positive effect of Ralgro on growth was significant in experiment 1 only ; no differences were found in blood urea nitrogen concentrations at three sampling dates between the Ralgro and control kids : $29.9,30.7 \mathrm{mg} / 100 \mathrm{ml}$ (1-st day on experiment) $: 22.3,22.2 \mathrm{mg} / 100 \mathrm{ml}$ (day 8 on experiment) ; 26.7, 26.1 mg/100 ml (day 30 on experiment). Ralgro implantation increased teat length in both experiments $(B<0.01)$ and teat length was found to be a practical way to distinguish implanted and non-implanted kids. Testicular circumference was not affected by the treatments.

In experiment 1 , the implanted kids spent more time sitting ( $46 \%$ vs. $35 \%$, day $10 ; 28 \%$ vs. $10 \%$, day $25 ; 74 \%$ vs. $40 \%$, day 45 ) and less time standing and jumping than the control kids $(B<0.05)$.

The rectal temperature was lower in the implanted than in the control kids $\left(39.22^{\circ} \mathrm{C}\right.$ vs. $39.67^{\circ} \mathrm{C}$, exp. $1, \mathrm{~B}<0.01 ; 39.10^{\circ} \mathrm{C}$ vs. $39.60^{\circ} \mathrm{C}$, exp. $\left.2, \mathrm{~B}<0.01\right)$ during ordinary spring days $\left(18^{\circ} \mathrm{C}, 55 \% \mathrm{RH}\right)$; during a hot-spell $\left(32.8^{\circ} \mathrm{C}, 13 \% \mathrm{RH}\right)$ not such differences were noted $\left(39.2^{\circ} \mathrm{C}\right.$ vs. $39.37^{\circ} \mathrm{C}$, exp. $1 ; 39.8^{\circ} \mathrm{C}, 39.8{ }^{\circ} \mathrm{C}$, exp. 2).

It seems that Ralgro implanting has some potential to promote growth in intact male kids fed highly energetic diets; however, this effect could be the result of several metabolic influences, as expressed by behavioural parameters and different patterns in rectal temperatures, instead of a mere anabolic effect.

Key words : Implant, growth-promoter, kid, Saanen, Ralgro. 